\title{
Proximate composition and overwintering strategies of Antarctic micronektonic Crustacea
}

\author{
J. J. Torres ${ }^{1}$, J. Donnelly ${ }^{1}$, T. L. Hopkins ${ }^{1}$, T. M. Lancraft ${ }^{1}$, A. V. Aarset ${ }^{2}$, D. G. Ainley ${ }^{3}$ \\ ${ }^{1}$ Dept of Marine Science, University of South Florida, 140 Seventh Ave. South, St. Petersburg, Florida 33701, USA \\ ${ }^{2}$ Lilleveien 5, N-6006 Ålesund, Norway \\ ${ }^{3}$ Point Reyes Bird Observatory, 4990 Shoreline Hwy, Stinson Beach, California 94970, USA
}

\begin{abstract}
Proximate (protein, lipid, carbohydrate and chitin) and elemental (carbon and nitrogen) composition were determined for 18 species of Antarctic micronektonic Crustacea, representing the majority of species found in the Antarctic water column. Individuals used in the analyses were captured during fall and winter; for 8 species data were collected in both seasons. Seven of the 8 species showed some evidence that combustion of body stores were an aid to surviving the winter months; comparison with data from other investigators suggests that most of the species inhabiting shallow and mid-depths exhibit some degree of combustion of body stores during winter. Three types of overwintering strategies are proposed for Antarctic zooplankton and micronekton. Type 1, exhibited by some calanoid copepods, is characterized by accumulation of large lipid deposits and a true dormancy, or diapause, during winter. Type 2, exhibited by euphausiids and hyperiid amphipods, is characterized by a marked reduction in metabolic rate, combustion of body substance, opportunistic feeding, but no true dormancy. Type 3, 'business as usual' is exhibited by decapods and gammarid amphipods; it is characterized by an absence of a winter reduction in metabolic rate, combustion of body stores in some species but a lack of combustion or accumulation of energy in others, and opportunistic feeding. Overwintering scenarios computed for Euphausia superba suggest that the impact of the winter season is most severe in the smaller size classes.
\end{abstract}

KEY WORDS: Proximate composition - Antarctic · Pelagic Crustacea - Overwinter

\section{INTRODUCTION}

The micronektonic crustacean assemblage of the Antarctic pelagial is a unique blend of cosmopolitan deep-living species and high-latitude endemics (Nagata 1986, Iwasaki \& Nemoto 1987, Lancraft et al. 1989, 1991). In the Atlantic sector, most of the cosmopolitan species disappear from the water column at the Weddell-Scotia confluence, a physical boundary that defines the northern limit of winter sea ice and separates the low and high Antarctic ecosystems (Lancraft et al. 1989). Species living south of the confluence must contend with the seasonal advance and retreat of pack ice and its influence on water column irradiance; all species must deal with highly pulsed seasonal production and uniformly cold temperatures in the upper $1000 \mathrm{~m}$ of the water column. In the Weddell Sea region primary production varies from $560 \mathrm{mg} \mathrm{C} \mathrm{m}^{-2} \mathrm{~d}^{-1}$ during spring in the vicinity of the ice edge at $60^{\circ} \mathrm{S}$, $40^{\circ} \mathrm{W}$ (Smith \& Sakshaug 1990) to $25 \mathrm{mg} \mathrm{C} \mathrm{m}^{-2} \mathrm{~d}^{-1}$ during winter (June-August) in the same region (W. O. Smith \& G. F. Cota unpubl.).

Extreme seasonality in primary production has its most severe impact on herbivorous Crustacea and, as a consequence, shapes their life histories. Many species of the best-studied pelagic Crustacea, the calanoid copepods, accumulate large quantities of lipid during the productive season and enter a state of true dormancy, or diapause, during the non-productive season, resuming normal feeding activity at the onset of phytoplankton growth (Sargent \& Henderson 1986, Conover 1988, Miller \& Clemons 1988). Larger pelagic Crustacea, including the euphausiids and amphipods, which have diets ranging from primarily herbivorous to omnivorous (Hopkins 1985, 1987, Hopkins \& Torres 1989) must also contend with seasonal swings in primary production. 
However, those species that have been examined show no exceptionally large accumulations of lipid (cf. Clarke 1980, 1984, Hagen 1988) nor do they exhibit a true dormancy such as that observed in the calanoids (Everson 1984). The metabolic strategies employed by micronektonic Crustacea to deal with the winter months are currently a matter for conjecture.

This paper describes the proximate and elemental composition of 18 species of Antarctic micronektonic Crustacea. Data are available for 8 of the species in both fall and winter which allow for an examination of their overwintering strategies. Detailed overwintering strategies were constructed for the krill Euphausia superba based on observed seasonal changes in metabolism and proximate composition.

\section{MATERIALS AND METHODS}

Collection of specimens. Specimens were collected during 2 cruises, March 1986 and June-August 1988, as part of the AMERIEZ (Antarctic Marine Ecosystem Research at the Ice Edge Zone) program. Due to the seasonal movement of the pack-ice edge, sampling locations for the 2 cruises were slightly offset from each other. In the austral fall (1986), sampling was conducted in the northwestern Weddell Sea in the vicinity of $65^{\circ} \mathrm{S}, 46^{\circ} \mathrm{W}$, while in the winter (1988), sampling took place in the southern Scotia Sea, $60^{\circ} \mathrm{S}, 40^{\circ} \mathrm{W}$. Station locations are given in Donnelly et al. (1990).

Sampling was conducted in the upper $1000 \mathrm{~m}$ with both an opening-closing Tucker trawl and a vertically towed, opening-closing plummet net. Sampling took place over 4 different zonal areas in relation to surface ice cover: (1) open water (i.e ice free); (2) marginal ice zone (MIZ); (3) consolidated pack ice in the vicinity $(<50 \mathrm{~km})$ of the MIZ; and (4) deep in the pack ice ( $>100 \mathrm{~km}$ from MIZ). Details of trawling procedures are described in Lancraft et al. $(1989,1991)$

On board, specimens were identified by species, measured to the nearest $\mathrm{mm}$ standard length, rinsed with fresh water, blotted dry, and individually sealed in polypropylene snap-cap vials and kept frozen at $-20^{\circ} \mathrm{C}$ until analysis in the laboratory. Prior to laboratory analysis, specimens were remeasured to the nearest $0.1 \mathrm{~mm}$ and massed to the nearest $0.0001 \mathrm{~g}$. Since the specimens were blotted dry before freezing, any water produced upon thawing was considered part of the wet mass. Specimens were ground in a hand-held glass tissue grinder with distilled water added to make a slurry of approximately $25 \mathrm{mg}$ dry mass (DM) $\mathrm{ml}^{-1}$ Large specimens were first cut up, partially homogenized in a Brinkman Polytron homogenizer, then transferred to a glass tissue grinder for final homogenization. Very small specimens were pooled as needed to provide sufficient sample material for analysis. In all cases, samples were dispensed from the slurry immediately upon completion of homogenization for the specific analyses.

Proximate and elemental composition analyses. Dry mass, ash mass, protein, lipid, carbohydrate and caloric value were determined using the procedures of Donnelly et al. (1990) with the addition of a chitin analysis. For chitin, aliquots of homogenate $(0.125 \mathrm{ml}$; $3.1 \mathrm{mg}$ DM) were dispensed into 2 preweighed test tubes. Samples were then dried to a constant weight, weighed, and hydrolyzed with $6 \mathrm{~N} \mathrm{HCl}$ at $100^{\circ} \mathrm{C}$ for 4 to $6 \mathrm{~h}$. Hexosamines were determined using the method of Tsuji et al. (1969), with D-glucosamine hydrochloride (Sigma) as the standard. The caloric contribution of chitin was estimated using the same conversion factor as that of carbohydrate $\left(4.1 \mathrm{kcal} \mathrm{g}^{-1}\right)$.

If sample size was sufficient, an additional slurry aliquot of $0.4 \mathrm{ml}(10 \mathrm{mg} \mathrm{DM}$ ) was dispensed into a screw-cap glass vial for determination of elemental composition. Samples were dried at $60^{\circ} \mathrm{C}$ to a constant mass and then stored in a vacuum desiccator. Analysis of carbon and nitrogen content was conducted using a Control Equipment Corporation Model 240XA automated CHN analyzer.

Data. Protein, lipid and carbohydrate components are expressed both as percent wet mass (\%WM) and percent ash-free dry mass (\%AFDM). Elemental components (carbon, nitrogen) are expressed only as percent ash-free dry mass; ratios of $C$ to $N$ are expressed as mass $\mathrm{C} /$ mass N. Minimum depth of occurrence (MDO: that depth below which $90 \%$ of the population lives; Childress \& Nygaard 1973) values were determined from day and night vertical distributional ranges tabulated from both 1986 and 1988 cruises (Hopkins \& Torres 1988, Lancraft et al. 1991, Lancraft unpubl.).

All regressions were computed using the least squares method. Data are reported as mean \pm standard deviation unless stated otherwise. Means were compared using either analysis of variance (ANOVA) or a Student's $t$-test with $\mathrm{p}<0.05$ as the cutoff for a significant difference Other statistical tests used in data analysis are reported in the text. Two $n$-values were used to express sample size in Tables 1 to 4 . Upper case (N) represents the number of replicate analyses performed for each species. Lower case $(n)$ represents the number of individuals of the species used in each replicate.

\section{RESULTS}

\section{Gammarid arophipods}

Water level varied from $74.7 \%$ of the wet mass in Cyphocaris richardi during fall to $83.7 \%$ in the deepestliving species, Parandania boecki, during winter (Tables 1 \& 2). C. richardi showed a significant in- 
Table 1. Standard length (SL), mass, water and ash level of Antarctic micronektonic Crustacea. N: number of complete analyses performed per species; n: number of individuals used per analysis; MDO: minimum depth of occurrence; WM: wet mass;

DM: dry mass; AFDM: ash-free dry mass; F: fall; W: winter. Standard deviation appears below the mean for each species

\begin{tabular}{|c|c|c|c|c|c|c|c|c|}
\hline $\begin{array}{l}\text { Group } \\
\text { Species }(N, n)\end{array}$ & Code & Season & MDO & $\begin{array}{c}\mathrm{SL} \\
\text { (range) }\end{array}$ & $\begin{array}{l}\text { Wet mass ( } \mathrm{g} \text { ) } \\
\text { (range) }\end{array}$ & $\begin{array}{c}\% \\
\text { Water }\end{array}$ & $\begin{array}{l}\text { AFDM } \\
(\% D M)\end{array}$ & $\begin{array}{c}\text { Skeletal ash } \\
(\% \mathrm{WM})\end{array}$ \\
\hline \multicolumn{9}{|l|}{ Amphipoda (Gammaridea) } \\
\hline Cyphocaris faueri $(6,1)$ & a & $\mathrm{F}$ & 40 & $\begin{array}{c}22.0 \\
(19-39)\end{array}$ & $\begin{array}{c}0.2380 \\
(0.10-0.73)\end{array}$ & $\begin{array}{r}76.4 \\
5.8\end{array}$ & $\begin{array}{l}78.1 \\
6.1\end{array}$ & $\begin{array}{l}3.8 \\
0.4\end{array}$ \\
\hline C. richardi $(5,1)$ & $b$ & $\mathrm{~F}$ & 340 & $\begin{array}{c}28.8 \\
(21-36)\end{array}$ & $\begin{array}{c}0.2151 \\
(0.11-0.44)\end{array}$ & $\begin{array}{r}74.7 \\
2.5\end{array}$ & $\begin{array}{c}76.2 \\
5.7\end{array}$ & $\begin{array}{l}4.8 \\
0.9\end{array}$ \\
\hline C. richardi $(5,1)$ & c & W & 100 & $\begin{array}{c}22.6 \\
(10.5-31)\end{array}$ & $\begin{array}{c}0.2222 \\
(0.08-0.41)\end{array}$ & $\begin{array}{r}74.8 \\
2.6\end{array}$ & $\begin{array}{c}82.4 \\
5.0\end{array}$ & $\begin{array}{l}3.6 \\
1.2\end{array}$ \\
\hline Parandania boecki $(2,2)$ & $d$ & W & 500 & $\begin{array}{c}18.5 \\
(13-24)\end{array}$ & $\begin{array}{c}0.2845 \\
(0.07-0.5)\end{array}$ & $\begin{array}{r}83.7 \\
2.3\end{array}$ & $\begin{array}{l}70.7 \\
9.0\end{array}$ & $\begin{array}{l}3.4 \\
0.8\end{array}$ \\
\hline \multicolumn{9}{|l|}{ Amphipoda (Hyperidea) } \\
\hline Cyllopus lucasii $(12,1)$ & e & $\mathrm{F}$ & 0 & $\begin{array}{c}19.8 \\
(17-23)\end{array}$ & $\begin{array}{c}0.2026 \\
(0.15-0.29)\end{array}$ & $\begin{array}{r}68.7 \\
4.2\end{array}$ & $\begin{array}{r}83.7 \\
2.7\end{array}$ & $\begin{array}{l}4.1 \\
0.4\end{array}$ \\
\hline C. lucasii $(8,1)$ & $\mathrm{f}$ & W & 0 & $\begin{array}{c}21.3 \\
(14-23)\end{array}$ & $\begin{array}{c}0.2422 \\
(0.09-0.31)\end{array}$ & $\begin{array}{r}77.6 \\
2.1\end{array}$ & $\begin{array}{r}79.1 \\
2.8\end{array}$ & $\begin{array}{l}3.5 \\
0.3\end{array}$ \\
\hline Hyperia macrocephala $(1,1)$ & g & $\mathrm{F}$ & 0 & 30.0 & 0.3824 & 72.8 & 76.8 & 5.3 \\
\hline Hyperiella antarctica $(1,5)$ & $\mathrm{h}$ & $\mathrm{F}$ & 0 & 9.6 & 0.0291 & 86.7 & 63.0 & 3.7 \\
\hline Primno macropa $(2,5)$ & $\mathrm{i}$ & $\mathrm{F}$ & 0 & $\begin{array}{c}14.3 \\
(14-14.5)\end{array}$ & $\begin{array}{c}0.0507 \\
(0.04-0.06)\end{array}$ & $\begin{array}{r}70.6 \\
1.7\end{array}$ & $\begin{array}{r}78.7 \\
2.4\end{array}$ & $\begin{array}{l}5.2 \\
0.3\end{array}$ \\
\hline P. macropa $(2,2)$ & j & W & 0 & $\begin{array}{c}14.7 \\
(12.4-17)\end{array}$ & $\begin{array}{c}0.1012 \\
(0.08-0.12)\end{array}$ & $\begin{array}{r}76.5 \\
0.2\end{array}$ & $\begin{array}{r}79.1 \\
2.8\end{array}$ & $\begin{array}{l}3.8 \\
0.6\end{array}$ \\
\hline Themisto gaudichaudi $(2,8)$ & $\mathrm{k}$ & W & 0 & $\begin{array}{c}17.0 \\
(16-18)\end{array}$ & $\begin{array}{c}0.0817 \\
(0.06-1.0)\end{array}$ & $\begin{array}{r}77.4 \\
0.5\end{array}$ & $\begin{array}{r}78.7 \\
1.4\end{array}$ & $\begin{array}{l}3.7 \\
0.2\end{array}$ \\
\hline Vibilia stebbingi $(1,4)$ & 1 & $\mathrm{~F}$ & 0 & 11.5 & 0.0401 & 71.4 & 81.4 & 4.3 \\
\hline V. stebbingi $(3,8)$ & $\mathrm{m}$ & W & 0 & $\begin{array}{c}10.5 \\
(10-10.8)\end{array}$ & $\begin{array}{c}0.0289 \\
(0.02-0.03)\end{array}$ & $\begin{array}{r}72.5 \\
5.2\end{array}$ & $\begin{array}{r}82.7 \\
1.5\end{array}$ & $\begin{array}{l}3.8 \\
1.4\end{array}$ \\
\hline \multicolumn{9}{|l|}{ Decapoda } \\
\hline Pasiphaea scotiae $(6,1)$ & $\mathrm{n}$ & F & 100 & $\begin{array}{c}21.7^{\mathrm{a}} \\
(10-39)\end{array}$ & $\begin{array}{c}1.4330 \\
(0.01-5.5)\end{array}$ & $\begin{array}{r}63.2 \\
2.7\end{array}$ & $\begin{array}{r}88.9 \\
5.3\end{array}$ & $\begin{array}{l}3.0 \\
1.6\end{array}$ \\
\hline P. scotiae $(8,1)$ & 0 & W & 1000 & $\begin{array}{c}21.3^{\mathrm{a}} \\
(11.5-41)\end{array}$ & $\begin{array}{c}1.9839 \\
(0.13-7.4)\end{array}$ & $\begin{array}{r}63.3 \\
2.1\end{array}$ & $\begin{array}{r}93.3 \\
1.3\end{array}$ & $\begin{array}{l}1.7 \\
0.5\end{array}$ \\
\hline Petalidium foliacium $(1,1)$ & $\mathrm{p}$ & $\mathrm{F}$ & 0 & $17.0^{\mathrm{a}}$ & 0.9967 & 71.8 & 90.2 & 1.8 \\
\hline P. foliacium $(3,1)$ & $q$ & W & 1000 & $\begin{array}{c}13.3^{\mathrm{a}} \\
(12-14)\end{array}$ & $\begin{array}{c}0.6886 \\
(0.51-0.84)\end{array}$ & $\begin{array}{r}67.4 \\
3.3\end{array}$ & $\begin{array}{r}93.5 \\
1.1\end{array}$ & $\begin{array}{l}1.2 \\
0.3\end{array}$ \\
\hline \multicolumn{9}{|l|}{ Euphausiacea } \\
\hline Euphausia superba $(23,1)$ & r & $\mathrm{F}$ & 0 & $\begin{array}{c}41.7 \\
(30-53)\end{array}$ & $\begin{array}{c}0.4531 \\
(0.21-1.4)\end{array}$ & $\begin{array}{r}73.3 \\
3.4\end{array}$ & $\begin{array}{r}83.9 \\
3.1\end{array}$ & $\begin{array}{l}3.2 \\
0.6\end{array}$ \\
\hline E. superba $(32,1)$ & $\mathrm{s}$ & W & 0 & $\begin{array}{c}37.3 \\
(29-53)\end{array}$ & $\begin{array}{c}0.3781 \\
(0.14-1.1)\end{array}$ & $\begin{array}{r}77.3 \\
3.4\end{array}$ & $\begin{array}{r}87.4 \\
1.7\end{array}$ & $\begin{array}{l}1.7 \\
0.5\end{array}$ \\
\hline E. triacantha $(9,3)$ & $\mathrm{t}$ & $w$ & 50 & $\begin{array}{c}6.6 \\
(5-11.2)\end{array}$ & $\begin{array}{c}0.1209 \\
(0.05-0.39)\end{array}$ & $\begin{array}{r}76.1 \\
3.6\end{array}$ & $\begin{array}{r}86.0 \\
1.3\end{array}$ & $\begin{array}{l}2.3 \\
0.7\end{array}$ \\
\hline Thysanoessa macura $(1,7)$ & $\mathrm{u}$ & $\mathrm{F}$ & 50 & $4.3^{\mathrm{a}}$ & 0.0133 & 70.4 & 86.9 & 2.9 \\
\hline T. macura $(6,5)$ & $\mathrm{v}$ & W & 50 & $\begin{array}{c}6.0^{\mathrm{d}} \\
(4.5-8.8)\end{array}$ & $\begin{array}{c}0.0618 \\
(0.02-0.10)\end{array}$ & $\begin{array}{r}76.9 \\
1.2\end{array}$ & $\begin{array}{r}88.0 \\
1.7\end{array}$ & $\begin{array}{l}1.7 \\
0.2\end{array}$ \\
\hline \multicolumn{9}{|l|}{ Mysidacea } \\
\hline Boreomysis rostrata $(2,1)$ & w & w & 550 & $\begin{array}{c}10.0^{\mathrm{a}} \\
(10-10.1)\end{array}$ & $\begin{array}{c}0.1428 \\
(0.13-0.16)\end{array}$ & $\begin{array}{r}75.8 \\
0.9\end{array}$ & $\begin{array}{r}85.9 \\
1.2\end{array}$ & $\begin{array}{l}2.4 \\
0.2\end{array}$ \\
\hline Eucopia australis $(2,1)$ & $\mathrm{x}$ & W & 1000 & $\begin{array}{c}13.0^{\mathrm{a}} \\
(10-16)\end{array}$ & $\begin{array}{c}0.9246 \\
(0.46-1.4)\end{array}$ & $\begin{array}{r}77.8 \\
1.8\end{array}$ & $\begin{array}{r}87.7 \\
0.9\end{array}$ & $\begin{array}{l}1.7 \\
0.0\end{array}$ \\
\hline Gnathophausia gigas $(4,1)$ & y & W & 1000 & $\begin{array}{c}16.8^{a} \\
(12-23)\end{array}$ & $\begin{array}{c}0.8968 \\
(0.27-1.4)\end{array}$ & $\begin{array}{r}69.4 \\
4.4\end{array}$ & $\begin{array}{r}89.5 \\
0.6\end{array}$ & $\begin{array}{l}2.2 \\
0.5\end{array}$ \\
\hline $\begin{array}{l}\text { Ostracoda } \\
\quad \text { Gigantocypris mulleri }(4,1)\end{array}$ & $z$ & W & 500 & $\begin{array}{c}16.3^{b} \\
(14-18)\end{array}$ & $\begin{array}{c}1.3638 \\
(0.81-1.9)\end{array}$ & $\begin{array}{r}91.3 \\
0.4\end{array}$ & $\begin{array}{r}79.9 \\
1.4\end{array}$ & $\begin{array}{l}0.5 \\
0.1\end{array}$ \\
\hline
\end{tabular}




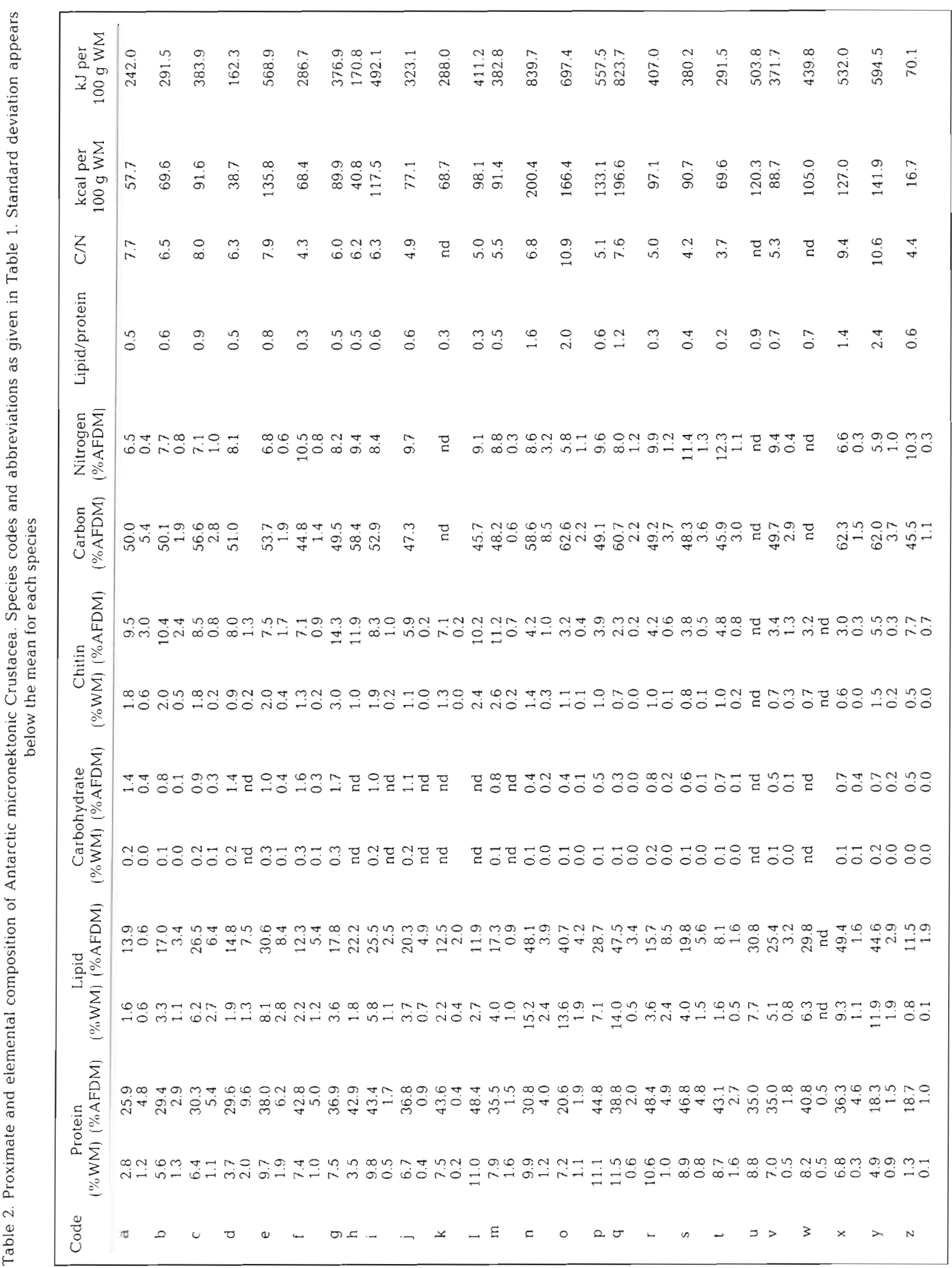


crease in lipid level ( $\%$ WM and \%AFDM) from the fall to the winter season which was mirrored by significant increases in carbon levels.

\section{Hyperiid amphipods}

Water level in the hyperiids ranged from $68.7 \%$ in Cyllopus lucasii during fall to $86.7 \%$ in Hyperiella antarctica during fall (Tables $1 \& 2$ ). Significant variability in compositional attributes was observed in $C$. lucasii and Primno macropa as a function of season. $C$. lucasiu showed significant increases in water level and nitrogen content in winter, whereas lipid, carbon, and energy levels showed a significant decline. P. macropa exhibited a significant increase in water level from fall to winter, accompanied by declines in protein (\%WM and \%AFDM), chitin (\%WM and \%AFDM) and energy level. Lipid level (\%WM and \%AFDM) showed a decline but probability was at the $\mathrm{p}<0.08$ level. Data were available for Vibilia stebbingi for fall and winter seasons, but the sample size for fall $(N=1)$ was too small for statistical comparison with winter. It is worth noting that there was a large drop in protein from fall to winter ( $\%$ WM and \%AFDM) that greatly exceeded the $95 \%$ confidence limits for the winter data.

Cyllopus lucasii exhibited a significant change in lipid level as a function of sampling zone in 1988 (Table 3). Individuals captured within the consolidated pack ice had a significantly lower lipid level (\%WM and \%AFDM) than those captured in the open water stations.

\section{Decapods}

Mean water level in the decapods $(66.4 \pm 4.1 \%$ WM $)$ was lower than that for the gammarid and hyperiid amphipods $(75.7 \pm 5.1 \% \mathrm{WM})$. The 2 species of decapods exhibited protein levels within the range observed for the gammarid and hyperiid amphipods. Lipid levels in the decapods generally exceeded those in the amphipods regardless of season. The lowest value, $7.10 \%$ WM for Petalidium foliaceum, is higher than any but the highest lipid value observed in the amphipods (Cyllopus lucasii: 8.05\%WM) and the highest, for Pasiphaea scotiae (fall), is nearly double that (15.19\%WM). Chitin levels in the decapods were at the low end of the range observed in the amphipods when expressed as \%WM. The lowest value was observed in $P$. foliaceum (winter, $0.99 \% W M$ ) and the highest in $P$. scotiae (fall, $1.38 \%$ WM).

$\mathrm{C} / \mathrm{N}$ ratios correlated well with lipid/protein ratios in this group; however, it would be easy to draw the wrong conclusions on seasonal changes in nutritional status from the data. The highest lipid/protein and highest $\mathrm{C} / \mathrm{N}$ values were observed in winter Pasiphaea scotiae, which had dropped $10 \%$ in protein (\%AFDM) and $8 \%$ in lipid (\%AFDM) from fall to winter. The higher $\mathrm{C} / \mathrm{N}$ value in winter P. scotiae is less a reflection of nutritional status than it is a measure of which compositional attribute dropped the least in the winter months. Energy level in this group scaled directly with lipid content and was far higher (557.5 to $839.7 \mathrm{~kJ}$ per $100 \mathrm{~g} \mathrm{WM}$ ) than that observed in the amphipods.

Pasiphaea scotiae was captured over a wide size range in both fall and winter. Data are broken down by size class in Table 4. A non-significant trend exists in both seasons with the largest size class (5.0 to $10.0 \mathrm{~g}$ ) exhibiting the highest lipid level and lowest protein level (\%WM and \%AFDM). A significant decline is observed in protein and lipid levels (\%WM and \%AFDM) from fall to winter whether the data for each season are lumped or are compared as a function of size.

\section{Euphausiids}

Water level in the euphausiids was similar to that of the amphipods with a range from $70.4 \%$ WM (Thysanoessa macrura, fall) to $76.9 \%$ WM (T. macrura, winter). Mean protein level (8.78\%WM) was intermediate between that of the hyperiid amphipods

Table 3. Compositional changes in relation to sampling zone. Zone 1 : open water 3 : consolidated pack ice in the vicinity $(<50 \mathrm{~km}$ away) of the marginal ice zone; 4 : heavy pack ice $(10 / 10$ cover $)>100 \mathrm{~km}$ from the marginal ice zone. Abbreviations as in Table 1

\begin{tabular}{|c|c|c|c|c|c|c|c|c|}
\hline Species & Zone & $\mathrm{N}$ & $\begin{array}{l}\text { Wet mass } \\
\qquad(\mathrm{g})\end{array}$ & $\% \mathrm{H}_{2} \mathrm{O}$ & \multicolumn{2}{|c|}{$\begin{array}{c}\text { Protein } \\
(\% \text { WM })(\% \text { AFDM })\end{array}$} & \multicolumn{2}{|c|}{$\begin{array}{c}\text { Lipid } \\
(\% \text { WM })(\% \text { AFDM })\end{array}$} \\
\hline Cyllopus lucasii (winter 1988) & $\begin{array}{l}1 \\
3\end{array}$ & $\begin{array}{l}3 \\
5\end{array}$ & $\begin{array}{l}0.2404 \\
0.2433\end{array}$ & $\begin{array}{l}76.0 \\
78.6\end{array}$ & $\begin{array}{l}7.56 \\
7.32\end{array}$ & $\begin{array}{l}39.72 \\
44.66\end{array}$ & $\begin{array}{l}3.50^{a} \\
1.46^{a}\end{array}$ & $\begin{array}{l}18.28^{\mathrm{a}} \\
8.65^{\mathrm{a}}\end{array}$ \\
\hline Euphausia superba (fall 1986) & $\begin{array}{l}1 \\
4\end{array}$ & $\begin{array}{l}13 \\
10\end{array}$ & $\begin{array}{l}0.7364 \\
0.3149\end{array}$ & $\begin{array}{l}72.7 \\
72.9\end{array}$ & $\begin{array}{l}10.80 \\
10.56\end{array}$ & $\begin{array}{l}48.44 \\
47.82\end{array}$ & $\begin{array}{l}5.28^{\mathrm{a}} \\
2.76^{\mathrm{a}}\end{array}$ & $\begin{array}{l}21.72^{\mathrm{a}} \\
12.08^{\mathrm{a}}\end{array}$ \\
\hline E. superba (winter 1988) & $\begin{array}{l}1 \\
3\end{array}$ & $\begin{array}{l}16 \\
16\end{array}$ & $\begin{array}{l}0.3318 \\
0.4214\end{array}$ & $\begin{array}{l}75.2^{\circ} \\
79.5^{\circ}\end{array}$ & $\begin{array}{l}9.48 \\
8.40\end{array}$ & $\begin{array}{l}45.27 \\
48.31\end{array}$ & $\begin{array}{l}4.72^{\mathrm{a}} \\
3.20^{\mathrm{a}}\end{array}$ & $\begin{array}{l}22.02^{\mathrm{a}} \\
17.65^{\mathrm{a}}\end{array}$ \\
\hline
\end{tabular}


Table 4. Compositional changes in relation to size. Abbreviations as in Table 1

\begin{tabular}{|c|c|c|c|c|c|c|c|c|c|c|}
\hline Species & $\begin{array}{l}\text { Size range } \\
\text { (g) }\end{array}$ & $\mathrm{n}$ & $\begin{array}{l}\text { Wet mass } \\
(\mathrm{g})\end{array}$ & $\% \mathrm{H}_{2} \mathrm{O}$ & $\begin{array}{r}\mathrm{PI}_{\mathrm{I}} \\
(\% \mathrm{WM}\end{array}$ & $\begin{array}{l}\text { in } \\
\text { oAFDM) }\end{array}$ & L & AFDM) & $\begin{array}{l}\text { Carbon } \\
\text { (\%AFDM) }\end{array}$ & $\begin{array}{l}\text { Nitrogen } \\
(\% \text { AFDM) }\end{array}$ \\
\hline $\begin{array}{l}\text { Pasiphaea scotiae } \\
\text { (fall 1986) }\end{array}$ & $\begin{array}{c}5.0-10.0 \\
1.0-5.0 \\
0.01-0.05\end{array}$ & $\begin{array}{l}1 \\
2 \\
3\end{array}$ & $\begin{array}{l}5.4502 \\
1.5327 \\
0.0275\end{array}$ & $\begin{array}{l}62.0 \\
65.8 \\
59.4\end{array}$ & $\begin{array}{r}8.0 \\
9.3 \\
10.9\end{array}$ & $\begin{array}{l}24.2 \\
32.2 \\
34.6\end{array}$ & $\begin{array}{l}19.1 \\
13.2 \\
15.4\end{array}$ & $\begin{array}{l}54.8 \\
45.4 \\
46.7\end{array}$ & $\begin{array}{l}69.0 \\
63.2 \\
48.8\end{array}$ & $\begin{array}{r}4.8 \\
6.7 \\
12.3\end{array}$ \\
\hline $\begin{array}{l}\text { P. scotiae } \\
\text { (winter 1988) }\end{array}$ & $\begin{array}{l}5.0-10.0 \\
0.5-1.0 \\
0.1-0.5\end{array}$ & $\begin{array}{l}2 \\
3 \\
3\end{array}$ & $\begin{array}{l}6.5239 \\
0.7001 \\
0.2411\end{array}$ & $\begin{array}{l}62.0 \\
63.4 \\
63.7\end{array}$ & $\begin{array}{l}6.1 \\
6.9 \\
7.1\end{array}$ & $\begin{array}{l}17.2 \\
20.9 \\
21.4\end{array}$ & $\begin{array}{l}17.4 \\
13.5 \\
12.4\end{array}$ & $\begin{array}{l}49.0 \\
41.0 \\
37.6\end{array}$ & $\begin{array}{l}64.0 \\
63.5 \\
58.6\end{array}$ & $\begin{array}{l}4.4 \\
5.6 \\
7.6\end{array}$ \\
\hline $\begin{array}{l}\text { Euphausia triacantha } \\
\text { (winter 1988) }\end{array}$ & $\begin{array}{c}0.1-0.5 \\
0.05-0.1 \\
0.01-0.05\end{array}$ & $\begin{array}{l}2 \\
5 \\
2\end{array}$ & $\begin{array}{l}0.3055 \\
0.0763 \\
0.0476\end{array}$ & $\begin{array}{l}71.2 \\
77.3 \\
77.8\end{array}$ & $\begin{array}{r}11.0 \\
8.2 \\
7.7\end{array}$ & $\begin{array}{l}45.8 \\
42.8 \\
41.2\end{array}$ & $\begin{array}{l}2.6 \\
1.5 \\
1.2\end{array}$ & $\begin{array}{r}10.7 \\
7.6 \\
6.6\end{array}$ & $\begin{array}{l}48.0 \\
46.6 \\
38.8\end{array}$ & $\begin{array}{r}12.5 \\
12.7 \\
9.8\end{array}$ \\
\hline
\end{tabular}

$(7.89 \%)$ and that of the decapods $(9.89 \%)$. Differences between the 3 groups were not significant. The euphausiids, decapods and hyperiids all exhibited significantly higher mean protein levels (\%WM) than the gammarids $(4.64 \%)$. Mean lipid levels among the euphausiids, hyperiids, and gammarids were not significantly different when expressed as WM or AFDM, but values for all 3 groups were significantly lower than that of the decapods. Chitin levels were a small fraction of the WM $(0.69$ to $0.95 \%)$ and AFDM (3.39 to $4.76 \%$ ) in the euphausiids, and in this regard were quite similar to the decapods. Chitin levels (AFDM) in both the euphausiids and decapods were significantly lower than those observed in the amphipods. The euphausiids showed lower lipid/protein ratios and C/N ratios than either the amphipods or decapods. Energy levels in the euphausiids scaled with lipid levels; they fell within the same range as those of the amphipods but were lower than those of the decapods.

Euphausia triacantha was captured over a sufficiently wide size range in 1988 to allow for analysis of composition versus size (Table 4). The largest sized individuals showed a significantly higher lipid level (\%WM and AFDM, $p<0.05$ ANOVA, LSD multiple range test) than the 2 smaller size classes and a nonsignificant trend toward a higher organic content (i.e. lower water level, higher protein level).

Sufficient numbers of Euphausia superba were captured in fall and winter to compare effects of zone of capture and season on proximate composition (Table 3 ). In fall, E. superba of comparable sizes were captured in open-water stations (zone 1) and in collections deep in the pack ice (zone 4). The krill collected in the pack ice showed a significant depletion in lipid whether expressed as \%WM or \%AFDM and little change in water or protein level. In winter, a similar trend was observed, with krill from stations in pack ice (zone 3) exhibiting significantly lower lipid levels (\%WM and \% AFDM) and significantly higher water levels than those captured in open water. If seasonal comparisons are made between individuals captured only in open water stations, water levels are significantly higher during the winter season and protein levels (\%WM) are significantly lower with no significant changes in the other attributes. If seasonal comparisons are made with individuals from pack-ice stations, protein (\%WM) is significantly lower, while water level and lipid (\% AFDM only) are significantly higher in the winter season. Lumped data for both seasons (as they are presented in Tables 1 \& 2) show a significantly higher water level and significantly lower protein level (\%WM) for winter krill with no significant changes in protein (\%AFDM) or lipid (\%WM or \%AFDM).

\section{Mysids}

Water levels within the mysids ranged from $69.4 \%$ in Gnathophausia gigas to $77.8 \%$ in Eucopia australis, a range similar to that observed in the amphipods and euphausiids. Lipid levels in the mysids were high, ranging from 6.29 to $11.87 \% W M$, and from 29.83 to 49.42 $\%$ AFDM. Chitin levels were low as a function of WM $(0.58$ to $1.51 \%)$ and AFDM (2.98 to $5.51 \%)$ - values most closely resembling the decapods and euphausiids. Carbon levels were high (62.01 to $62.26 \%$ AFDM) as were $\mathrm{C} / \mathrm{N}$ ratios (9.42 to 10.58 ). Energy levels reflected the high lipid levels with values ranging from 439.8 to $594.5 \mathrm{~kJ}$ per $100 \mathrm{~g}$ WM. The mysids as a group most closely resembled the decapods in all attributes but water level, which was much greater in the mysids. The decapods and mysids are the 2 groups containing the largest and deepest-living species listed in Tables $1 \& 2$.

\section{Ostracods}

Gigantocypris mulleri exhibited the highest water level of all species examined $(91.3 \%)$. The energy level of G. mulleri (70.1 kJ per $100 \mathrm{~g}$ WM) reflected its watery composition and was the lowest value of all species examined. 


\section{Depth of occurrence}

Water, protein (\%WM and \%AFDM) and lipid (\%WM and \%AFDM) levels were examined for trends with species' depth of occurrence. Water, protein (\%WM only) and lipid (\%WM only) levels showed no significant correlation with depth. Protein ( $y, \%$ AFDM) declined significantly with depth ( $x, M D O)$ in fall (1986) according to the equation $y=42.14 x^{-0.077 \pm 0.024}$ $\left(\mathrm{r}^{2}=0.723, \mathrm{p}<0.05\right)$, and in winter (1988): $y=$ $41.78 x^{-0.060 \pm 0.023}\left(r^{2}=0.339, p<0.05\right)$. Lipid level (\%AFDM) showed no significant correlation with depth in fall data, but in winter a significant increase in lipid ( $y, \%$ AFDM) with depth $(x, M D O)$ was observed: $y=41.78 x^{0.103 \pm 0.044}\left(r^{2}=0.298, p<0.05\right)$.

\section{Overall trends}

Several interesting trends were exhibited in the data set as a whole. Water level ( $y, \% W M)$ scaled reciprocally with lipid level ( $x, \%$ AFDM) according to the equation: $y=-0.302 \pm 0.084 x+82.16\left(\mathrm{r}^{2}=0.407\right.$, $\mathrm{p}<0.05)$. Similar tests on water versus protein or chitin (\%AFDM) showed no significant correlation. The relationship between water and lipid has a 2 -fold implication. First, among species, a low water content implies a high lipid level. This trend is best illustrated by examining the decapods and mysids. The 4 species with the lowest water levels show 4 of the 5 highest lipid levels (Tables $1 \& 2$ ). The exception to the trend is Eucopia australis, which shows a high lipid and high water level. Second, within a species, an increase in water level may indicate lipid combustion or loss. This is suggested by results from the hyperiids Cyllopus lucasii and Primno macropa, which both show a drop in lipid and increase in water level during the winter season. However, results from the amphipod Cyphocaris richardi and the decapod Pasiphaea scotiae show no change in water level with change in lipid level. Euphausia superba (open water) shows an increased water level in winter with no change in lipid (\%AFDM) but a drop in protein ( $\%$ WM); and in pack ice shows a large increase in water level accompanied by a drop in protein (\%WM) and increase in lipid (\%AFDM). Without question, water and lipid are the most plastic of the compositional attributes.

Ash level ( $y, \% D M)$ scaled directly with water level $(x, \% W M)$ according to the equation: $y=0.544 \pm 0.169 x$ $-23.99\left(r^{2}=0.354, p<0.05\right)$, suggesting that a large fraction of the inorganic solutes within the species were from the hemolymph and cell sap. The skeletal ash content (Table 1) is that fraction of ash which is not accounted for by the water content within a species and is assumed to originate in the exoskeleton. The amphipods show the highest skeletal ash $(\mathrm{p}<0.05$, Mann-Whitney $U$-test) of the 5 orders of Crustacea examined and, in addition, show the highest chitin content (\%WM and \%AFDM , p < 0.05, Mann-Whitney $U$-test). The elevated skeletal ash and chitin levels of the amphipods suggest that they have a more robust exoskeleton than the other orders of Crustacea examined here.

Carbon level ( $y, \%$ AFDM) for species listed in Table 1 scales positively with lipid $(x, \%$ AFDM) according to the equation: $y=0.409 \pm 0.039 x+42.07\left(\mathrm{I}^{2}=0.868\right.$, $p<0.05$ ). Thus, much of the variability in carbon is explained by changes in lipid level among the species. A similar regression of carbon versus protein is not significant. Nitrogen level ( $y, \%$ AFDM) scales directly with protein $(x, \%$ AFDM $)$ according to the equation: $y=0.120 \pm 0.040 x+4.41\left(r^{2}=0.342, p<0.05\right)$. If Gigantocypris mulleri is left out as an outlier, the equation for nitrogen versus protein reverts to: $y=$ $0.169 \pm 0.035 x+2.49\left(\mathrm{r}^{2}=0.596, \mathrm{p}<0.05\right)$. Variability in nitrogen level is largely due to changes in protein. The other likely source of nitrogen variability, chitin, does not show any significant relation with nitrogen.

The ratio of carbon to nitrogen is presumed to be a good indicator of the lipid/protein ratio and therefore of physiological status. The 2 ratios showed a good correlation. Lipid/protein ( $y, \%$ AFDM) scaled with $\mathrm{C} / \mathrm{N}$ ( $x, \% \mathrm{AFDM}$ ) according to the equation: $y=$ $0.244 \pm 0.036 x-0.766\left(r^{2}=0.729, p<0.05\right)$.

\section{DISCUSSION}

\section{Seasonal changes}

Overwintering mechanisms employed by Antarctic pelagic species are of paramount interest in discerning whether successful species show specialized, systemspecific adaptations or whether overwintering strategies are modifications of those employed by lower latitude species. From an a priori standpoint, at least 3 mechanisms for overwintering exist in the pelagic Crustacea. The first strategy (Type 1) would be one similar to that employed by herbivorous copepods which accumulate a large lipid reserve, usually wax. ester, and enter a dormant, or diapause state that is cued by the external photoperiod (cf. Conover 1988, Miller \& Clemons 1988). At the other extreme (Type 3) would be a business-as-usual strategy in which metabolic activity would not be modulated appreciably; opportunistic feeding coupled with some combustion of tissue would suffice to carry the species through the winter months. Clearly, the Type 3 option would only be open to carnivores and omnivores. A third potential strategy (Type 2) would be an intermediate between 
the first 2 in which metabolic activity is modulated downward due to either starvation or an external cue. Some opportunistic feeding and substantial depletion of body substance would suffice to carry the species through the winter months. Our evidence points to strategies 2 and 3 as being the primary ones employed by the crustaceans examined in this study.

Eight species were captured in both fall and winter (Table 1). Five of those species were captured in sufficient numbers for statistical analyses (Cyphocaris richardi, Cyllopus lucasu, Primno macropa, Pasiphaea scotiae and Euphausia superba). Three additional species had only singleton analyses in the fall season (Vibilia stebbingi, Petalidium foliaceum and Thysanoessa macrura), but since the single analysis in 2 of the 3 cases ( $P$. foliaceum excepted) was the result of pooled specimens it in itself is an average. Two more species (Themisto gaudichaudi and Euphausia triacantha) for which we have winter data can be compared with the fall data of other investigators. Clarke (1984) reports fall (March-April) lipid levels in $T$. gaudichaudi and E. triacantha to be $6.55 \%$ WM and 4.12 $\%$ WM, respectively. Our winter values for those 2 species are 2.18 and $1.64 \% \mathrm{WM}$, respectively. Thus, in 8 out of 10 cases, a seasonal change in composition, either an increase in water level or decline in protein or lipid level, suggests that tissues are being combusted as fuel during the winter.

All the hyperiid amphipods for which seasonal data are available show some level of winter depletion in compositional attributes. We are attributing changes in lipid levels among the hyperiids to combustion of lipid rather than to reproductive activity on the basis of observed changes in metabolic rates and the fact that, in at least Themisto gaudichaudii, reproduction shows a marked peak in the spring (Kane 1966). Metabolic rates of Cyllopus lucasii and Vibilia stebbingi are significantly lowered in the winter (Torres et al. 1994) and the respiratory data on Primno macropa are highly suggestive of a reduction as well. In addition, both C. Iucasii and $V$. stebbingi are associated with salps as adults (Madin \& Harbison 1977, Lancraft et. al. 1989), and $V$. stebbingi is an obligate parasite on salps during its early development. The low biomass of salps during the winter months (Everson 1984, Lancraft et al. 1991) make a fall-winter reproductive strategy an unlikely one. Our data suggest a Type 2 overwintering strategy for the hyperiids as a group.

All of the deeper-living species examined in this study, which would include the gammarid amphipods, the decapods, the mysids and the ostracod Gigantocypris mulleri, have access to the diapausing populations of lipid-rich calanoid copepods that sink out of the euphotic zone to overwinter below $300 \mathrm{~m}$ (Foxton 1956, Hopkins et al. 1993). The downward shift in zoo- plankton biomass out of the euphotic zone is not restricted to calanoids. The majority of zooplankton biomass is found below $300 \mathrm{~m}$ during the winter season (Hopkins et al. 1993). Since the deeper-living species are zooplanktivorous (Hopkins et al. 1993), their food supply is not heavily impacted by the winter season. Biomass of zooplankton does not decline appreciably; it simply moves downward.

The decapod Pasiphaea scotiae is the only deepliving species that exhibits a significant decline in protein (9.88 to $7.16 \% \mathrm{WM}$ ) and lipid (15.19 to $13.57 \%$ WM) from fall to winter but the change in composition is not accompanied by a drop in metabolic rate (Torres et al. 1994). In contrast, Petalidium foliaceum, like the gammarid amphipod Cyphocaris richardi, shows an increase in lipid (\%WM and \%AFDM) during the winter months. C. richardi shows no depression in metabolic rate, and seasonal data on metabolism are unavailable for P. foliaceum. Clarke \& Holmes (1986) observed that lipid levels in $P$. foliaceum from waters around South Georgia were highly variable in both seasons with no obvious trend from season to season. Their data and the data from the present study both suggest that winter has limited impact on the deeperliving species, leading us to conclude that the overwintering strategy for the gammarids, decapods and mysids would be a Type 3, business-as-usual, strategy.

The euphausiids as a group all show some evidence of compositional depletion during the winter, either within the present data set (Euphausia superba. Thyanoessa macrura) or in comparison with the data sets of other investigators ( $E$. triacantha; Clarke 1984, see above). The data set on E. superba is by far the most complete of the 3 and allows for some detailed discussion of the overwintering strategy of the species. The key to understanding how E. superba and other species relying partly or wholly on primary production make it through the winter at the ice edge is to appreciate their metabolic flexibility. E. superba is an excellent paradigm, as we believe its overwintering strategy (Type 2) is typical of many of the micronektonic Crustacea occupying the upper $200 \mathrm{~m}$ in the Antarctic water column.

First, lipid content is highly variable within individuals captured in a single net tow, and mean lipid content is highly variable in space and time during both fall and winter (Fig. 1). Protein also exhibits considerable variability (Fig. 2) but over a smaller range. Mean lipid levels of individuals captured within $2 \mathrm{~d}$ of each other but at different locations during fall (9 and 11 March) and winter (18 and 20 June) show significant differences $(p<0.1$, LSD multiple range test). Second, variability in individual lipid level within a given season is as great as that between seasons. Thus, while we see declines in overall mean lipid 


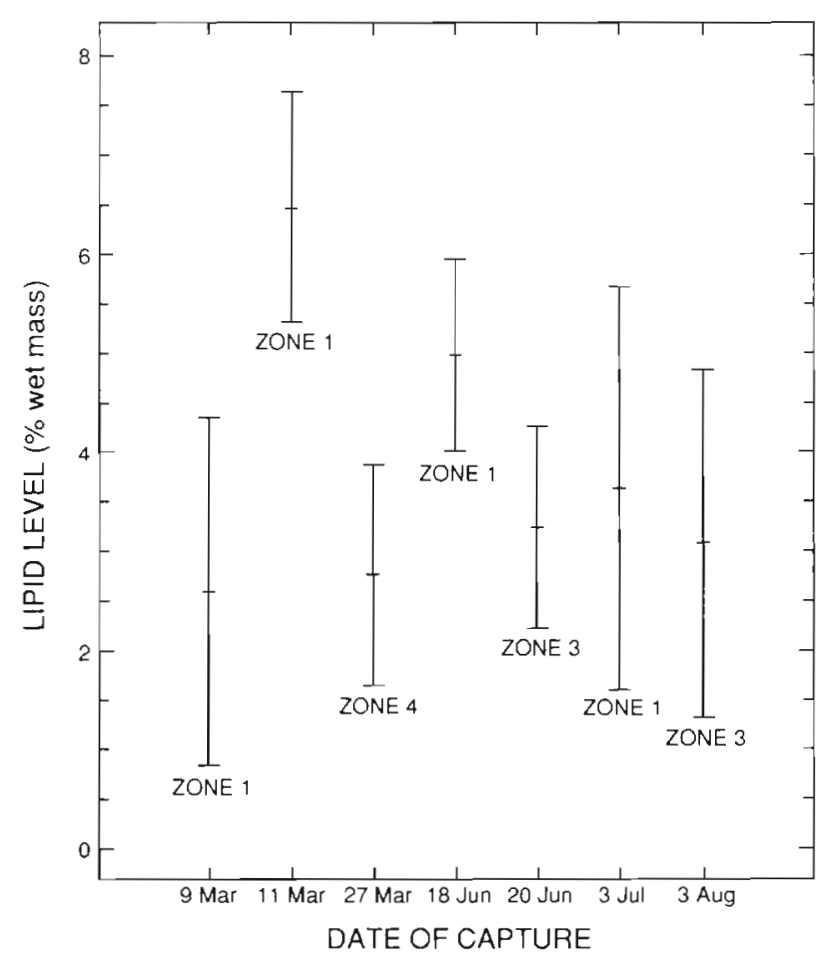

Fig. 1. Euphausia superba. Lipid level as a function of capture dat. Zone 1: open water; 3: consolidated pack ice in the vicinity $(<50 \mathrm{~km}$ away) of the marginal ice zone; 4 : heavy pack ice $(10 / 10$ cover $)>100 \mathrm{~km}$ from the marginal ice zone. Data are expressed as means $\pm 95 \%$ confidence limits. March values are from fall 1986; June, July and August values are from winter 1988

levels between fall and winter in individuals captured in open water, observed variability in lipid level strongly suggests that at the edge of the pelagic pack ice many individuals will be entering the winter season depleted in lipid. In the fall, much of the variability in lipid level may be ascribed to reproductive activity, as the species was actively reproducing during this time. In the winter, variability in lipid may be attributed to differences in the combustion of lipid by individuals, as the species does not reproduce during the winter (Quetin \& Ross 1991). Alternatively, variability in lipid levels among individuals during the winter season may be due to the lipid level present when they entered the season. The source of the variability is less important than the fact that it occurs, and that it is unlikely that the entire population enters the winter season with high lipid levels. The variability in lipid levels observed in our data is typical for the species at all times of year for which data are available (cf. Clarke 1980, 1984, Hagen 1988).

To demonstrate the energetic costs of overwintering, we have constructed hypothetical overwintering scenarios for 2 different size classes of Euphausia superba: $50 \mathrm{~mm}$ and $30 \mathrm{~mm}$ (Figs. $3 \& 4$ ), assuming

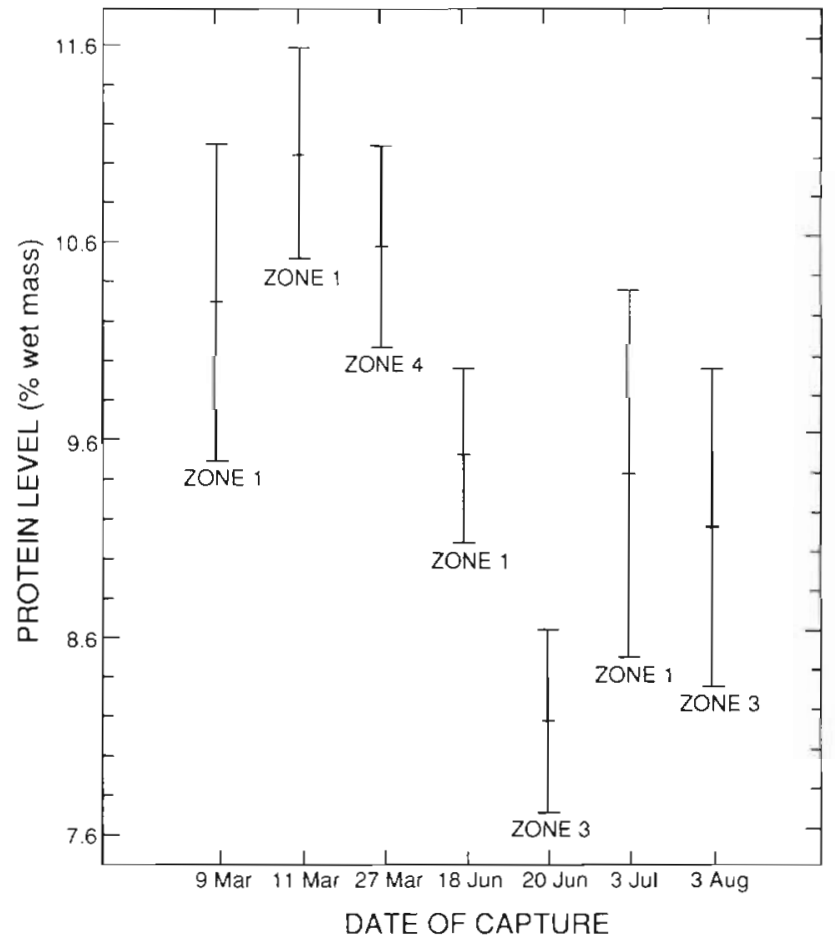

Fig. 2. Euphausia superba. Protein level as a function of capture dat. Zone 1: open water; 3: consolidated pack ice in the vicinity $(<50 \mathrm{~km}$ away) of the marginal ice zone; 4 : heavy pack ice $(10 / 10$ cover $)>100 \mathrm{~km}$ from the marginal ice zone. Data are expressed as means $\pm 95 \%$ confidence limits. March values are from fall 1986; June, July and August values are from winter 1988

that individuals are combusting themselves for energy, i.e. that no feeding occurs. Each of the figures is a flow chart with multiple starting and ending points. Each size class enters the winter with the wet mass typical of its length as determined from a length-mass regression of the fall data, but with different initial compositional characteristics. The compositional characteristics used as starting points were: the mean protein and lipid values for each particular size class during the fall; the highest mean protein and lipid values recorded in our fall data (which were for the $50 \mathrm{~mm}$ size class); and the overall mean for the fall season for those individuals captured in open water (Table 3). Four hypothetical ending points were used for each size class. We assumed that low primary production during the austral winter would preclude normal feeding for a period of $120 \mathrm{~d}$. For the first 3 ending points we obtained a final mass by assuming that individuals molt 3 times during the $120 \mathrm{~d}$ period, shrinking by $2 \%$ of their body length per molt. This is within the range of intermolt intervals and molt increments reported by Quetin \& Ross (1991). We then obtained the mass associated with that length for winter animals from a length-mass regression. Winter ani- 
$50 \mathrm{~mm}$ INDIVIDUAL

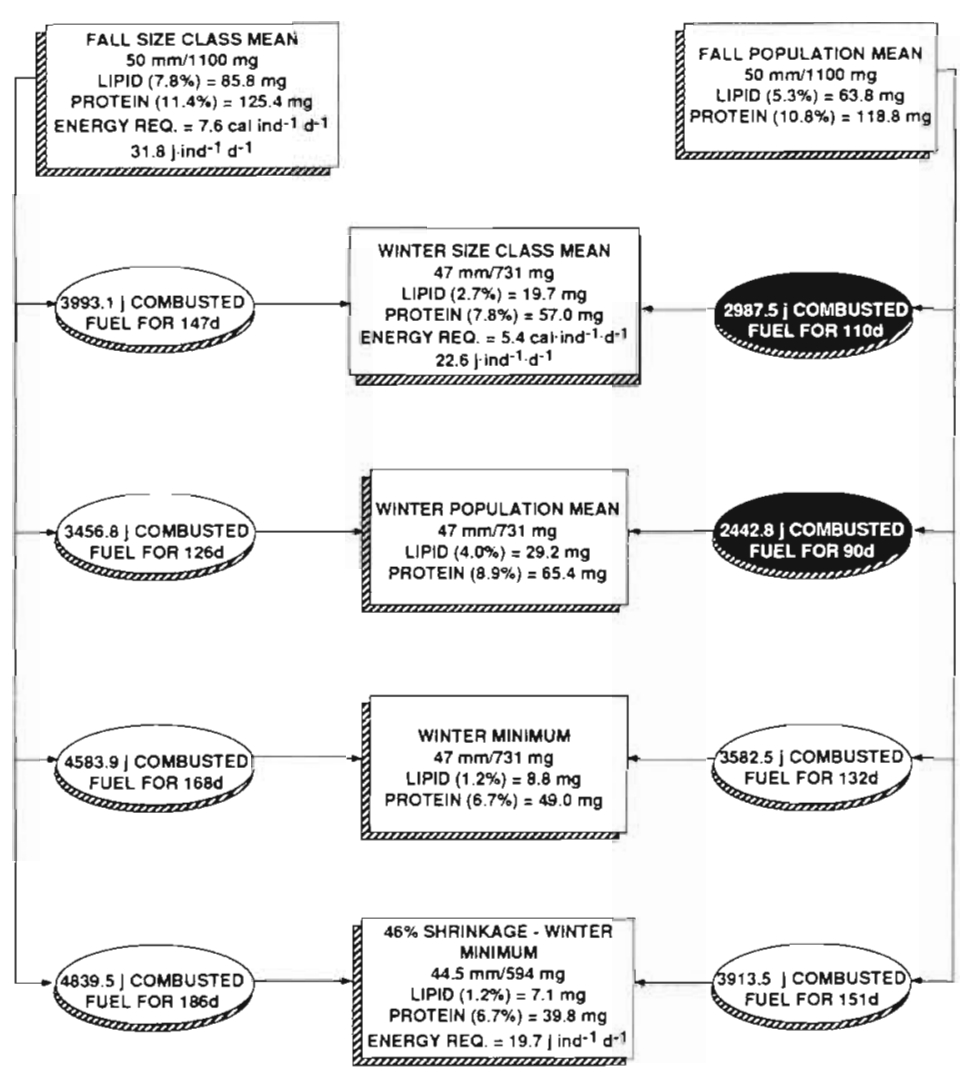

Fig. 3. Overwintering scenario for $50 \mathrm{~mm}$ Euphausia superba assuming that no feeding occurs. The figure is a flow chart with 2 starting and 4 ending points. The $50 \mathrm{~mm}$ individual enters the winter with the wet mass typical of its length but with different starting compositional characteristics. The compositional characteristics used as starting points were: the mean protein and lipid values for the $50 \mathrm{~mm}$ class during fall (fall size class mean) and the mean for the fall season for those individuals captured in open water (fali population mean). For 3 ending points, a final mass was obtained by assuming that individuals molt 3 times during a $120 \mathrm{~d}$ period, shrinking by $2 \%$ of their body length per molt, and obtaining the mass associated with that length for winter specimens from a lengthmass regression. Protein and lipid values were then assigned to the now shrunken individual using the winter means for that size class (winter size class mean), the overall winter population means (winter population mean), and the lowest protein and lipid values recorded in our data (winter minimum). The fourth and final ending point for class was obtained by assuming that individual E. superba are capable of shrinking a maximum of $46 \%$ of their original body weight, and then assigning the lowest protein and lipid values in our data to that mass to come up with a low end member ( $46 \%$ shrinkage-winter minimum). Energy requirements were computed from respiration measurements. Black ovals indicate that fuel combusted during the shrinkage from the initial to final values defined by the connecting arrows are incompatible with survival for $120 \mathrm{~d}$ without food mals exhibit a reduction in body volume relative to fall animals so that individuals of the same length weigh less during the winter (present data; Quetin \& Ross 1991). We then assigned protein and lipid values to the now shrunken individual using the winter means for that size class, the overall winter population means, and the lowest protein and lipid values recorded in our data to come up with 3 of the 4 hypothetical end points. The fourth and final ending point for each size class was obtained by assuming that individual E. superba are capable of shrinking a maximum of $46 \%$ of their original body mass and then assigning the lowest protein and lipid values in our data to that mass to come up with a low end number. The figure for maximum shrinkage was obtained from the work of Ikeda \& Dixon (1982), who kept several E. superba alive in the laboratory for $211 \mathrm{~d}$ without feeding; survivors dropped an average of $46 \%$ from their initial weight. Differences in total lipid and protein content ( $\mu \mathrm{g}$ ind. ${ }^{-1}$ ) from each starting point to each ending point were computed and converted to energy values using conversion factors of $9.45 \mathrm{cal} \mathrm{mg}^{-1}$ for lipid and $4.8 \mathrm{cal} \mathrm{mg}^{-1}$ for protein (Brett \& Groves 1979), and then converted to joules by assuming that $1 \mathrm{cal}=4.19 \mathrm{~J}$ (Pennycuick 1988). Daily energy requirements during the shrinking process were computed by using winter respiration values from Torres et al. (1994) for each starting and ending size and then taking the mean for the 2 sizes. The mean oxygen consumption rate was converted to an energy consumption rate using an equivalent of $19.40 \mathrm{~J} \mathrm{ml}^{-1} \mathrm{O}_{2}$ (Brett \& Groves 1979). This figure was divided into the total energy difference between starting and ending points to arrive at the value for how long the body fuel would last.

The overwintering scenarios, while hypothetical, underscore 3 important points. First, the impact of winter food deprivation is highly dependent on the composition of individuals entering the winter months and especially on initial lipid levels. For animals of 50 and $30 \mathrm{~mm}$, combustion of the body mass accompanying three $-2 \%$ molts was sufficient to yield enough fuel for $120 \mathrm{~d}$ when starting at maximum lipid levels and ending at minimum. Second, the impact of food deprivation is size-dependent. At any time of year individuals of $30 \mathrm{~mm}$ exhibit lower average lipid values than their larger counterparts (Figs. $3 \& 4$ ) (Clark 1984, Hagen 1988). The overwintering scenarios constructed for the $30 \mathrm{~mm}$ size class using initial and final size class compositional means, or the population means, show that insufficient fuel exists to overwinter without radical drops in weight. The larger, 


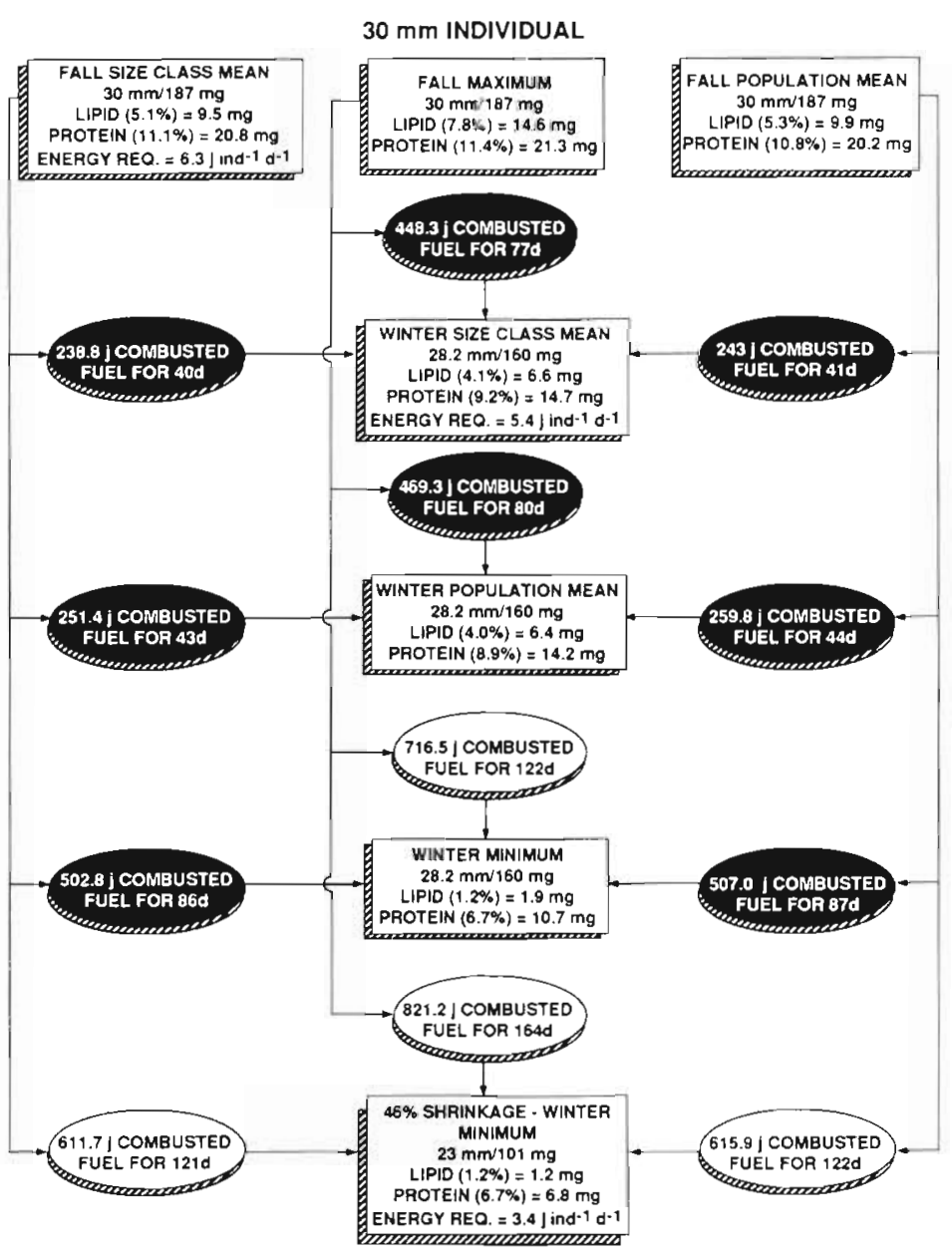

Fig. 4. Overwintering scenario for $30 \mathrm{~mm}$ Euphausia superba. Initial and final points computed as in Fig. 3 but an additional starting point was used: fall maximum, which was comprised of the highest mean protein and lipid values recorded in fall data (which were from the $50 \mathrm{~mm}$ size class). Black ovals indicate that fuel combusted during the shrinkage from the initial to final values defined by the connecting arrows are incompatible with survival for $120 \mathrm{~d}$ without food the hyperiids or other euphausiids in this data set show large accumulations of lipid that would suggest a major pre-winter storage such as the increase in wax ester lipids observed in pre-diapause copepods (see review in Sargent \& Henderson 1986). Further, those species that have been examined, including Cyllopus lucasii, Themisto gaudichaudi, Vibilia antarctica, E. superba and E. triacantha, show either triglycerides or phospholipids as the major lipid component (Clarke 1984). Wax ester is a minor fraction of the total lipid in all 5 cases.

The level of metabolic reduction (about $50 \%$ ) observed in Cyllopus Lucasii, Vibilia antarctica, and Euphausia superba is equivalent to that expected of a starved animal. In fact, the metabolic rate measurements by Ikeda \& Dixon (1982) on their starved $E$. superba were virtually identical to our winter metabolic rates. The reduction in metabolism in all cases is most likely due to the fact that growth is not occurring at the reduced food levels typical of the winter months (cf. Jobling 1985). Alternatively, the absence of growth and the reduced metabolism associated with it may be an adapted metabolic response to winter conditions induced by an environmental cue.

In lieu of the true dormancy exhibited by calanoid copepods, the larger Crustacea can accommodate low food supply by a strategy of metabolic flexibility. Combustion of body mass, opportunistic feeding, a lowered metabolic rate, and, at least in one confirmed case, negative growth, all combine to yield a viable overwintering strategy.
$50 \mathrm{~mm}$ individuals have little problem, as virtually all possible scenarios result in $120 \mathrm{~d}$ of fuel. Third, the energetics analysis presented here, along with the growing body of literature describing exploitation by krill of algae, detritus and zooplankton associated with the winter pack-ice cover (Marschall 1988, Daly 1990, Hopkins et al. 1993) suggest that winter feeding is not the exception, but the rule. What is most likely for krill in the vicinity of the ice edge is a strategy of opportunistic feeding and combustion of body stores, slowly losing ground over time until production begins in the spring.

Our data on proximate composition and metabolism of Antarctic Crustacea suggest that the overwintering strategy of Euphausia superba (Type 2) is typical of many species rather than an exceptional case. None of
Acknowledgements. This paper is dedicated to Jose Torres (1920-1992), philosopher and scholar. The research was supported by NSF DPP 8420652 and DPP 8819533 to J.J.T. and T.L.H., and DPP 8419894 to D.G.A. We thank the captains and crews of the RV 'Melville', 'Polar Duke', and the USCGC 'Glacier' for their support. Kendra Daly has been an invaluable source of support both on board ship and during manuscript preparation. Many thanks to our other colleagues in the AMERIEZ program for sharing data and lending support at sea.

\section{LITERATURE CITED}

Brett, J. R., Groves, T. D. D. (1979). Physiological energetics. In: Hoar, W. S., Randall, D. J., Brett, J. R. (eds.) Fish physiology, Vol. 8. Academic Press, New York, p. 280-352

Childress, J. J., Nygaard, M. H. (1973). The chemical composition of midwater fishes as a function of depth of occurrence off Southern California. Deep Sea Res. 20: 1093-1109 
Clarke, A. (1980). The biochemical composition of krill, Euphausia superba Dana, from South Georgia. J. exp. mar. Biol Ecol. 43: 221-236

Clarke, A. (1984). The lipid content and composition of some Antarctic zooplankton. Br. Antarct. Surv. Bull. 63: 57-70

Clarke, A., Holmes, L. J. (1986). Lipid content and composition of some midwater crustaceans from the Southern Ocean. J. exp. mar. Biol. Ecol. 104: 31-51

Conover, R. J. (1988). Comparative life histories in the genera Calanus and Neocalanus in high latitudes of the northern hemisphere. Hydrobiologia 167/168: 127-142

Daly, K. L. (1990). Overwintering development, growth, and feeding of larval Euphausia superba in the Antarctic marginal ice zone. Limnol. Oceanogr. 35: 1564-1576

Donnelly, J., Torres, J. J., Hopkins, T. L., Lancraft, T. M. (1990). Proximate composition of Antarctic mesopelagic fishes. Mar. Biol. 106: 13-23

Everson, I. (1984). Marine zooplankton. In: Laws, R. M. (ed.) Antarctic ecology, Vol. 2. Academic Press, London, p. $463-490$

Foxton, P. (1956). The distribution of the standing crop of zooplankton in the Southern Ocean. 'Discovery' Rep. 28: $191-326$

Hagen, W. (1988). Zur Bedeutung der Lipide im antarktischen Zooplankton. Ber. Polarforsch. 49: 1-129

Hopkins, T. L. (1985). Food web of an Antarctic midwater ecosystem. Mar. Biol. 89: 197-212

Hopkins, T. L. (1987). The midwater food web in McMurdo Sound, Ross Sea, Antarctica. Mar. Biol. 96: 93-106

Hopkins, T L., Lancraft, T. M., Torres, J. J., Donnelly, J (1993). Community structure and trophic ecology of zooplankton in the Scotia Sea marginal ice zone in winter (1988). Deep Sea Res. 40:81-105

Hopkins, T. L., Torres, J. J. (1988). The zooplankton community in the vicinity of the ice edge, western Weddell Sea, March 1986. Polar Biol. 9: 79-87

Hopkins, T. L., Torres, J. J. (1989). Midwater food web in the vicinity of a marginal ice zone in the western Weddell Sea. Deep Sea Res. 36: 543-560

Ikeda, T., Dixon, P. (1982). Body shrinkage as a possible overwintering mechanism of the Antarctic krill, Euphausia superba Dana. J. exp. mar. Biol. Ecol. 62: 143-151

Iwasaki, N., Nemoto, T. (1987). Distribution and community structure of pelagic shrimps in the Southern Ocean between $150^{\circ} \mathrm{E}$ and $115^{\circ} \mathrm{E}$. Polar Biol. 8: 121-128

Jobling, M. J. (1985). Growth. In: Tytler, P., Calow, P. (eds.)

This article was submitted to the editor
Fish energetics: new perspectives. Croom Helm Ltd, Beckenham, p. 213-230

Kane, J. E. (1966). The distribution of Parathemisto gaudichaudii (Guer.) with observations on its life history in the $0^{\circ}$ to $20^{\circ} \mathrm{E}$ sector of the Southern Ocean. 'Discovery' Rep. 34: 163-198

Lancraft, T. M., Torres, J. J., Hopkins, T L. (1989). Micronekton and macrozooplankton in the open waters near Antarctic ice edge zones (AMERIEZ 1983 and 1986). Polar Biol. 9: 225-233

Lancraft, T M., Hopkins, T. L., Torres, J. J., Donnelly, J. (1991). Oceanic micronektonic/macrozooplanktonic community structure and feeding in ice covered Antarctic waters during the winter. Polar Biol. 11: 157-167

Madin, L. P., Harbison, G. R. (1977). The associations of Amphipoda Hyperiidae with gelatinous zooplankton. I. Associations with Salpidae. Deep Sea Res. 24: 449-463

Marschall, H.-P. (1988). The overwintering strategy of antarctic krill under the pack-ice of the Weddell Sea. Polar Biol. 9: 129-135

Miller, C. B., Clemons, M. J. (1988). Revised life history analysis of large grazing copepods in the Subarctic Pacific Ocean. Prog. Oceanogr. 20: 293-313

Nagata, K. (1986). Amphipod crustaceans from surface waters of the Southern Ocean during 1983-1984 summer. Mem. natn. Inst. polar Res. (spec. issue) 40: 259-276

Pennycuick, C. J. (1988). Conversion factors, SI units and many others. University of Chicago Press, Chicago

Quetin, L. B., Ross, R. M. (1991). Behavioral and physiological characteristics of the Antarctic krill, Euphausia superba. Am. Zool. 31: 49-64

Sargent, J. R., Henderson, R. J. (1986). Lipids. In: Corner, E. D. S., O'Hara, S. C. M. (eds.) The biological chemistry of marine copepods. Clarendon Press, Oxford, p. 59-108

Smith, W. O., Sakshaug, E. (1990). Polar phytoplanktor. In: Smith, W. O. (ed.) Polar oceanography, Part B, Chemistry, biology, and geology. Academic Press, San Diego, p. $477-526$

Torres, J. J., Aarset, A. V., Donnelly, J., Hopkins, T. L., Lancraft, T. M., Ainley, D. G. (1994). Metabolism of Antarctic micronektonic Crustacea as a function of depth of occurrence and season. Mar. Ecol. Prog. Ser. 113: 207-219

Tsuji, A., Kinoshita, T., Hoshino, M. (1969). Analytical chemical studies on amino sugars. II. Determination of hexosamines using 3-methyl-2-benzothiazolone hydrazone hydrochloride. Chem. Pharm. Bull. 17: 1505-1510

Manuscript first received: July 26,1993

Revised version accepted: July 18,1994 